\title{
CONTEMPLATION: THE RATIO OF CONSCIOUS AND UNCONSCIOUS
}

\author{
Garnik V. Akopov \\ Samara State University of Social Science and Education (Russia)
}

\begin{abstract}
In psychological science, the concept of contemplation is not included in the most important categories of psychology, such as activity, consciousness, personality. The dictionary meanings of the term "contemplation" are ambiguous. In psychology, in addition to the categorical analysis of contemplation (S.L. Rubinstein) and its attribution to fundamental concepts (A.V. Brushlinsky), there are also interpretations of contemplation, which are synonymous to intuition (A. Bergson) and meditation (V.F. Petrenko, Han F. De Wit), insight (preconceptual thinking - T.K. Rulina), mystical states (W. James, P.S. Gurevich). Contemplation, unlike intuition, meditation and insight, does not have a previous reportable history.

In our studies, contemplation is considered as an unconscious mental phenomenon that exists in the forms of a process, state, and also the properties of an individual (contemplative personality). Not coinciding with the processes of attention, memory, perception, thinking, etc., contemplation, however, is activated on their basis. The difference lies in the uncontrollability of this process, since its contents are not presented to consciousness. Therefore, contemplation is also different from dreams, experiences, intentions and other internally substantive mental phenomena. Despite the fact that consciousness does not have access to the content of contemplation (access-consciousness), the process itself is realized by man. In this we see the difference between contemplation as unconscious activity and Freudian understanding of the unconscious. Other differences are: involuntary entry and random exit from the state of contemplation; emotional equipotentiality of contemplation, i.e. the invariability of the emotional background of contemplation from the beginning to the exit from it. In ontogenesis, contemplation is most clearly represented in infancy, in youth, and in old age, as well as during periods of age and other life crises. Reminiscences of students record the age range from 11 to 17 years as the most saturated with contemplation; least at the age of 6-8 years (L.S. Akopian). Contemplation as an unconscious activity periodically replaces purposeful activity, contributing to the maturation, correction, transformation of the person's life meanings in their micro-, meso- and macro-macro dimensions.

Contemplation also fulfills the function of partially liberating oneself from an excess of affairs, concerns, plans, aspirations, and other forms of conscious activity. The development of practice-oriented forms of actualization of contemplation will expand the range of psychotherapeutic methods.
\end{abstract}

Keywords: Contemplation, consciousness, unconsciousness, method.

\section{Introduction}

Modern high technology has actively taken over nearly all spheres of human life. The boundaries between natural and man-made environments, natural and artificial, conscious and unconscious have been blurred. The phenomenon of the unconscious, mastered by science, art, and utilized in the practice of therapy in the versions of Sigmund Freud, Karl Jung, and Paul Diel, among others, is acquiring a different outline today. In this context, contemplation can be compared to a stone, which has remained aloof from the so-called construction site of the unconscious. At the same time, the theme of contemplation is widely represented in esoteric and religious publications. Scientific interest in the problem of contemplation in Samara was initially realized in the format of the Volga Seminar (2011), and then at the All-Russian Conference. On this basis, the prospects for overcoming the well-known opposition of consciousness and the unconscious by means of the category of contemplation were determined [Contemplation ... 2013; Akopov, 2014; Rulina; Shestun, Podorovskaya].

In the system of human knowledge, the concept of contemplation is clearly represented in philosophy, art, religious teachings and practices, as well as social and humanitarian sciences. In narrow scientific research, such as the sciences of consciousness, neuroscience, and cognitive science, contemplation may be associated with the problem of reciprocity of phenomenal and cognitive (psychological) consciousness [Chalmers; Honderich; Revonsuo; Akopov, 2010, etc.]. Most often, 
contemplation is associated with perceptual (visual) consciousness; much less often - with low-order thinking [Genaro] and other mental processes. The phenomenology of contemplation as a partially conscious process can be revealed in subjective reports, i.e. in representations from the First-person perspective. A group of students is favourable for this in terms of procedural possibilities, in comparison with other age groups.

\section{Background}

Earlier, in research carried out jointly with L.S. Akopyan [Akopyan, Akopov], the emotional equi-potentiality of contemplation as a mental state was shown among psychology students 18-19 years old, who provided textual descriptions of their reminiscences about the experience of contemplation, in the age period from the moment of first self-awareness ("I remember myself from.. years,"; as a rule from 5-6 years to their current age). Content analysis of the diverse content of students' reminiscences in the category of "experience" and others, showed that the state of contemplation does not carry any strong emotional manifestations, despite the fact that the participants do not remember (do not recall) the original experience, i.e. emotional state before the onset of the process of contemplation. The very state of contemplation was characterized by the survey participants as calm, pacifying, evenness in mood; that is, without significant changes in the "potential" of emotions in the process of contemplation.

\section{Survey Results}

\subsection{Preliminary}

Based on the results of the pilot study, a contemplative activity questionnaire was designed. The structure of the questionnaire makes it possible to determine the respondents' ideas about contemplation and personal experience of experiencing this state. Participants were 18-19 year old students studying the pedagogical issues of inclusive education. In a group of 11 people, 37 descriptions of contemplation were observed: $42 \%$ of them define this state as "immersion in oneself" ("in their own world", "in their thoughts, feelings, dreams", "withdrawal into oneself", detachment from the external the world", "being in your world", "experiencing in your world ", "experiencing in yourself ", etc.); somewhat more - $46 \%$ of respondents define contemplation as a state of calm ("humility"; "pleasure", including - aesthetic, "pacification", "unity with the world", "with the surrounding space", "openness to the world", etc.); the rest $-12 \%$, identify contemplation as "pensiveness", which, apparently, can also be attributed to states.

\subsection{Deeper analysis}

In the aggregate of students' answers to clarifying questions about the peculiarities of activity during contemplation and its content, we managed to identify the following aspects of the individual's immersion in contemplation: 1). The procedural aspect is characterized by "immersion or withdrawal into oneself", "stopping the internal dialogue", "calmness", "spiritual harmony", "enjoying what is happening", "feeling like a third person", "observer", etc .; 2). The content aspect is determined by the following statements of the participants: "you think about important things in life", "about love for nature and people, about fate", "you look at beauty, nature, contemplate it and immediately thoughts about your life, about the past begin to creep into your head. , future, present", "something that has not been analyzed unconsciously emerges", "the situation is assessed without feelings and emotions "; 3). Situational aspect: "contemplation comes in nature", "when alone", "when you look or listen to something beautiful or something calm, beautiful", etc .; 4). Functional (effective) aspect: "contemplation helps to correctly analyze what is happening", "gain experience", "sometimes we do not have enough time to stop, contemplate beauty and think", "harmony with oneself is achieved", "internal clamps go away", "Perception changes", "calming the mind", "reevaluation of events without emotions, without regret, as an observer from the outside", "after contemplation, lightness and joy", etc.

Choosing the conditions specified in the text of the questionnaire that stimulate the process of visual contemplation, the survey participants in approximately the same way recognized as such: "view from the height of a mountain peak", "sea distance", "clouds floating in the sky", "horizon distance", "burning bonfire ", "a flowing river". To this list, some students added "starry sky", "a view of a bright moon." Auditory contemplation is equally stimulated by the "sound of the sea" and "birdsong", a little less - by a "lingering song"; very rarely - by the "ticking of the clock" and "an audible quiet conversation." Psychomotor activity that promotes contemplation, according to the choice of the participants, consists of the processes of walking and monotonous actions. The quantitative distribution of the selected visual, auditory and kinesthetic stimuli of contemplative states in 11 participants is as follows: 71,36 and 21 stimulating situations. 


\subsection{Excerpts of reflection}

In the representations of the experience of contemplation, the survey participants identified a significant variability in the content of contemplation: "thoughts themselves come and you think about everything and nothing", "at one moment - thoughts and memories, and at another - just emptiness", "someone is in the state of absence of any thoughts, while others, at the moment of contemplation, there is a reassessment of the life situation, but without emotions and regret", "sometimes, when you think about a situation or question for a long time, you yourself drive yourself into this state", "in contemplation, internal activity is carried out unconsciously, unperceived" and so on.

Participants attribute approximately the same emotional colouring in the process of contemplation. These are mainly states such as: calmness, happiness, satisfaction, freedom, warmth, or a sense of unity. Quite often there are answers that deny any emotional accompaniment to contemplation: "without feelings and emotions", "disconnection from the whole world", "feeling like a third person, an observer." It is interesting to note that in the descriptions of the moment in time prior to contemplation, the participants do not record any emotions. At the same time, after contemplation, they feel calmness, relaxation, "a pleasant aftertaste from the process", "everything falls into place in thoughts", a feeling of harmony, lightness, and joy are attributed. Single statements attributing to an active post-contemplative state: "the feeling that something needs to be changed or some action to be performed right now", or "there is a feeling of irritation if interrupted."

Assessing the frequency of experiencing moments of contemplation, the majority of students chose the mid-position in the proposed scale (very often, often, from time to time, rarely, very rarely). Those who notice the state of contemplation in other people describe the following external signs: "a person looks out with concentration at one point, and does not react to the environment", "looks at something, but is immersed in himself"; thoughtful, peaceful. The ability to evoke a state of contemplation at will, to manage it, was recognized by very few participants. At the same time, as a means of immersion in contemplation, a very limited range of possibilities is noted ("choose a quiet place", "in nature", "alone", "after reading a book", "looking out the window", "at an uninteresting lecture", "You go somewhere for a long time," "I think for a long time over some question."

Most of the participants state that contemplation almost always comes spontaneously. In the final stage of the survey, the participants compared contemplation with such mental states as drowsiness (dreaming), thoughtfulness, inspiration, insight, remembering, concentration, meditation, observation, and imagination. The comparison had to be carried out according to three criteria: a) complete coincidence (identity); b) a certain similarity; c) absolute dissimilarity. The participants attributed a high degree of similarity of contemplation (more than $80 \%$ ) to states of thoughtfulness and observation; a certain similarity - with inspiration and meditation; complete dissimilarity - with drowsiness and recollection.

\section{Discussion}

Our results, paradoxically, largely coincide with the results obtained in studies on samples of schoolchildren (16-17 years old) and students (20-21 years old), in previously published works [Akopyan, $2013 ; 2014]$. The paradox lies in the independence of the results from the various instruments used and the time distance of 7-8 years. Such reproducibility of the phenomenon of contemplation speaks of it as an important, non-random mental property of a person. At the same time, contemplation cannot be attributed to any of the well-known classes of human mental properties, be it processes (attention, memory, etc.), states, features (factors) of a person. So, the process of attention (direction and concentration of mental activity) cannot be identified with contemplation, which is characterized only by concentration in the absence of an object of direction (excluding preconception). Contemplation can carry traces of memory, but it is not a purposeful process in remembering, reminiscing, memorizing, etc.

More broadly, it can be argued that contemplation also does not coincide with the phenomena of consciousness, in particular, with sensory, perceptual, affective and cognitive consciousness. As likely known, one of the generally accepted criteria for the awareness of one or another human activity is the ability to give an account of one's actions, deeds, experiences, and one's states. The phenomenology of contemplation presented above does not allow for speaking about the complete accountability of the process of contemplation to the individual. Only the state of contemplation itself, an immersion in it, is clearly realized. What is being contemplated (excluding pre-contemplative objects of mental activity) is not explicitly conscious, while in sensory, perceptual and other types of consciousness, the object is directly represented in the field of consciousness.

In non-classical psychology [Vygotsky], consciousness is identified by the attributes of arbitrariness, generalization, and mediation. On these grounds, it also cannot be argued that contemplation is a fully conscious process. If one tries to attribute contemplation to unconscious, mental phenomena, then it is also clear that this is not a Freudian libido, nor a Jungian archetype, nor Diel's vanity, etc. At the same time, it is similar to the manifestations of the Ego according to Freud, the Self according to Jung, etc. 
Turning to modern studies of consciousness, one can pay attention to such identification of consciousness as "qualia" [Revonsuo]. Of the "five leading ideas" that make it possible to identify consciousness [Honderich], the idea of qualia, in our opinion, allows us to assign the status of consciousness to contemplation. At the same time, qualia belongs to the category of phenomenal consciousness, which, in contrast to perceptual, cognitive and other types of consciousness, defines the so-called "Hard Problem" of consciousness [Chalmers; Honderich; Revonsuo and others]. Difficulty, i.e. the unsolved problem of the scientific explanation of phenomenal consciousness, again does not allow for the inclusion of contemplation in the categorical space of consciousness.

\section{Conclusion}

Thus, contemplation appears to be an important component of the known mental processes, states, and personality traits. A feature of the process of contemplation is its awareness by the individual as a special state, despite the fact that the object of contemplation and the very "flow" of the process are not perceived. The functional feature of contemplation is an internal, hidden processing, or correction or transformation of micro- and macro-meanings of human life. It is also important that this process of rethinking is meaningfully hidden and emotionally positive for the individual. Based on the foregoing, the process of contemplation can be qualified as spontaneous psychological self-therapy of the individual.

\section{Acknowledgements}

This article was prepared as part of a scientific project No. 19-013-00816, supported by a grant from the Russian Foundation for Basic Research, on the topic "Multidimensionality of consciousness as a problem of modern psychology: typology of approaches and design of a system of categorical spaces".

\section{References}

Акопов Г.В. Психология сознания: Вопросы методологии, теории и прикладных исследований. М.: Изд-во «Институт психологии РАН», 2010.

Акопов Г.В. Созерияание в категориальной системе современной психологии: теоретические и прикладные аспекты / Под ред. Член-корреспондента РАН, доктора психологических наук, профессора В.Ф. Петренко. - Самара: Издательство ВЕК 21. - 2014.

Акопян Л.С., Акопов Г.В. Эмочиональная эквипотенциильность созерцания как психического состояния // Психология психических состояний: актуальные теоретические и прикладные проблемы. Казанский федеральный университет, 14-16 ноября 2013 г. Часть 1. Казань: Изд-во «Отечество», 2013. С. 3-8.

Акопян Л.С. Представления о феномене созериания у студентов // Созериание как современная научно-теоретическая и прикладная проблема: материалы Всероссийской конферениии / под ред. Г.В. Акопова, Е.В. Бакшутовой. Самара, 21 мая 2013 г - Самара: ПГСГА, 2013, c.144-147.

Акопян Л.С. Определение понятия «созерцание» и роль опыта переживания в личностном самоопределении учащихся // Личностная идентичность: вызовы современности: материаль Всерос. науч.-практ. конф. (с иностранным участием) / под ред. З.И. Рябикиной и В.В. Знакова. - Краснодар: Кубанский гос. Ун-т, Майкоп: Адыгейский гос. ун-т; М.: Институт психологии PAH; 2014, c. 96-97.

Рулина Т.К. Созерцание: познание категории. Учебное пособие к спецукурсу по истории психологии / под ред Г.В. Акопова. - Самара. ПГСГА, 2013.

Созериание как современная научно-теоретическая и прикладная проблема: Материаль Всероссийской конференции / под ред. Г.В. Акопова, Е.В. Бакшутовой, Самара, 21 мая 2013 г. Самара: ПГСГА, 2013.

Шестун Е.В., Подоровская И.А. Созерияание в теоретическом осмыслении и практиках мнотеистических религий / под ред. Г.В. Акопова. - Самара: СамРУПС, 2014.

Chalmers, D.J. (2010). The Character of Consciousness. New York, NY: Oxford University Press.

Genaro, R.J. (2012). The Consciousness Paradox: Consciousness, Concepts and Higher Order Thonghts. Cambridge, Massachusetts: The MIT Press.

Honderich, T. (2014). Actual Consciousness. Oxford, UK: Oxford University Press.

Revonsuo, A. (2018). Foundations of Consciousness. New York, NY/Oxon, UK: Routledge.

Vygotsky, L. S. (1978). Mind in society: The development of higher psychological processes. Cambridge, MA (USA): Harvard University Press. 